\title{
Nutrient accumulation at different supply rates in experimental Mediterranean planktonic communities
}

\author{
Montserrat Vidal* ${ }^{*}$ Carlos M. Duarte \\ Instituto Mediterráneo de Estudios Avanzados (IMEDEA), CSIC - Universitat de les Illes Balears, Miquel Marqués 21, \\ 07190 Esporles (Mallorca, Islas Baleares), Spain
}

\begin{abstract}
A mesocosm experiment was conducted between June 18 and July 8, 1997, in the Bay of Blanes (NE Spain) to test for the effect of nutrient inputs on Mediterranean plankton communities. The experiment involved a gradient of daily nutrient additions to mesocosms (14 m high, $4.2 \mathrm{~m}^{2} \mathrm{cross}^{-}$ sectional area and $33 \mathrm{~m}^{3}$ effective volume), which were scaled to the nutrient loading of the Bay of Blanes in summer $\left(0.64 \mu \mathrm{M} \mathrm{N} \mathrm{d}^{-1}\right.$, referred to as the 'business as usual' control). This paper deals with the accumulation of nutrients in different size components $(0.2-2,2-20$ and 20-200 $\mu \mathrm{m})$ of the community and the efficiency with which these size components retain the added nutrients. Summer Mediterranean plankton responded significantly to nutrient additions by increasing their biomass, up to more than 100-fold that initially present in the enclosed water, and by changing the community structure, from an initial dominance of picoplankton to increased dominance of the 2-20 $\mu \mathrm{m}$ size component of the community (which contributes to more than $90 \%$ of the accumulated $\mathrm{N}$ and $\mathrm{P}$ ) as the nutrient load increased. Though the initial community was able to accumulate nutrients exceeding the already high summer loading of the Bay of Blanes and thus acted as strong nitrogen (N) and phosphorus (P) sink, it was unable to trap the nutrients above a certain threshold: 4 -fold (for N) and 8-fold (for P) the 'business as usual' load. Conspicuous biomass increases were most noticeable after the nutrient inputs were increased 16-fold that value. Nevertheless, the biomass response was relatively low and involved a low efficiency $(8 \%)$ in the trapping of added nutrients. As efficiencies were transiently higher (of $50 \%$ or even greater, between consecutive sampling days) we suggest factors other than a low assimilation by osmotrophs as responsible for the resilience of the plankton community for the trapping of nutrients in biomass in response to nutrient additions. The tendency of a lower biomass response to nutrient additions in the warm oligotrophic Mediterranean waters than in more eutrophic waters, if confirmed, should have profound consequences concerning the management of the coastline and the delineation of critical nutrient loadings.
\end{abstract}

KEY WORDS: Nutrient accumulation $\cdot$ Coastal plankton $\cdot$ Size structure $\cdot$ Eutrophication $\cdot$ Mesocosm $\cdot$ NW Mediterranean Sea

Resale or republication not permitted without written consent of the publisher

\section{INTRODUCTION}

Increasing nutrient inputs, as experienced in many coastal zones, are expected to lead to increased plankton production. While this is associated with the accu-

*Present address: Laboratoire d'Océanographie BiologiqueUMR 7621, Laboratoire Arago, BP 44, 66651 Banyuls-surMer Cedex, France. E-mail: mvidal@arago.obs-banyuls.fr mulation of nutrients in the particulate phase, the rate of accumulation of nutrients in plankton biomass is, however, not clear as yet. Knowledge of the capacity of the plankton community to acquire and accumulate nutrients with increasing inputs is, however, most important, since this accumulation is one of the triggers of the problems associated to eutrophication (Boynton et al. 1982, 1996, Hecky \& Kilham 1988, Oviatt et al. 1989, Tamminen \& Kuosa 1998). 
Nutrient addition experiments have demonstrated a rapid accumulation of nutrients into the biomass of moderately eutrophic Atlantic plankton communities (Kononen et al. 1993, Bleijswijk et al. 1994, Hein \& Riemann 1995). However, this may not apply to other systems, such as the Mediterranean coast, where heterotrophic processes can be nutrient limited (Thingstad et al. 1998) and dominate over autotrophic processes (Satta et al. 1996), for increased plankton biomass requires autotrophic processes to dominate over heterotrophic ones. The efficiency of nutrient accumulation in planktonic food webs is also likely to depend on the rates of carbon and nutrient flow from the autotrophs and picoheterotrophs, acting as entry points of nutrients to the food web, to other components of the food web. Nutrient accumulation in small organisms is likely to be conducive to a lower retention than if these were transferred to larger, longer-lived, organisms. Indeed, the size structure of the plankton community is likely to exert an important control on nutrient accumulation, since both the channelling of nutrients along food webs, and the rates of most processes occurring in plankton systems are dependent on organism size (Peters 1983, Cousins 1985, Platt 1985, Moloney \& Field 1991, Chisholm 1992).

Oligotrophic Mediterranean plankton communities are dominated by small organisms, particularly in summer (Hagström et al. 1988, Selmer et al. 1993, Agawin et al. 1998), when heterotrophic processes are important (Satta et al. 1996). Hence, it can be hypothesised that the efficiency of oligotrophic, warm Mediterranean plankton to accumulate nutrients is small. Unfortunately, the effects of nutrient inputs on Mediterranean plankton food webs have only been addressed in a limited number of studies (Zweifel et al. 1993, Dolan et al. 1995, Vaulot et al. 1996, Pitta et al. 1998, Thingstad et al. 1998, Zohary \& Robarts 1998), so that the capacity to predict eutrophication-related problems in the Mediterranean is limited.

Here we test the effect of increasing nutrient inputs on the accumulation of nutrients in different size components in a summer Mediterranean plankton community. We do so by using a series of large $\left(33 \mathrm{~m}^{3}\right.$ effective volume) mesocosms receiving a gradient of nutrient inputs. We also examine the stoichiometry of nutrient accumulation in the different size classes $(0.2-2,2-20$ and 20-200 $\mu \mathrm{m}$ ) and the efficiency at which these size components retain the added nutrients.

\section{METHODS}

The experiment was conducted between June 18 and July 8, 1997, near the town of Blanes (NE Spain). The mesocosms, mounted on a floating platform, were moored at $35 \mathrm{~m}$ depth, at about $2 \mathrm{~km}$ offshore from the town of Blanes. This coastline is rather exposed, and subject to substantial wave action (Cebrián et al. 1996, Duarte et al. 1999), so that the 35 m thick water column at the study site is well mixed throughout the summer, and no measurable thermal stratification occurs in the layer occupied by the mesocosm units (Cebrián et al. 1996). The mesocosms were set up the day preceding the initiation of the nutrient addition, and were filled by gravity, followed by the use of water pumps. The bags were only partially filled to prevent rupture due to wave action and to allow the propagation of turbulence across the walls of the mesocosm units, thereby maintaining well-mixed conditions. The mixing time of water in the mesocosm units was determined experimentally, through dye additions at the end of the study. It was on the order of 5 to $10 \mathrm{~min}$ on a relatively calm day. The experimental period was characterised by unusual wave action for the summer period, so that the units were inspected regularly by SCUBA divers to check for damage. The experimental design involved a gradient of nutrient additions to mesocosms following a geometric series of nutrient inputs. We used a series of 7 large mesocosms consisting of $14 \mathrm{~m}$ deep and $4.2 \mathrm{~m}^{2}$ cross-sectional area bags, with a nominal and effective volume of 50 and $33 \mathrm{~m}^{3}$, respectively. The nutrient additions included a treatment equivalent to the nutrient loading in summer at the Bay of Blanes (0.64 $\mu \mathrm{M} \mathrm{N} \mathrm{d}^{-1}$; Duarte et al. 1999), the 'business as usual' load that represents a control for the nutrient input received in the ambient waters, a treatment equivalent to half that nutrient loading, and increased nutrient additions exceeding the 'business as usual' control by 2-, 4-, 8- and 16-fold. In addition, a mesocosm receiving only the background atmospheric inputs (approximately $0.005 \mu \mathrm{M} \mathrm{N} \mathrm{d}^{-1}$; Duarte et al. unpubl. data) was included. Nutrients were added to the mesocosms on alternate days, following the collection of samples, as solutions of $\mathrm{NH}_{4} \mathrm{Cl}, \mathrm{KH}_{2} \mathrm{PO}_{4}$ and $\mathrm{Na}_{2} \mathrm{SiF}_{6}$ in seawater. Phosphorus and silicon were added to maintain their average summer stoichiometry with nitrogen in the sedimentary flux (20N:7Si:1P; Duarte unpubl. data). Nitrogen was added as ammonium, the dominant form of summer nitrogen inputs to the Bay of Blanes (Duarte unpubl. data). Additional details on the experimental design are reported in Duarte et al. (2000a).

The bags were inspected every $4 \mathrm{~d}$ by divers to check for signs of deterioration. In addition to the absence of damage to visual inspection, the conservative behaviour of salinity inside the bags, despite important changes in the ambient waters, indicates the absence of exchange with the interior. The fluorescein additions conducted at the end of the experiment also showed no evidence of exchange between the mesocosms and the ambient waters. 
Samples to determine dissolved inorganic nutrients and particulate carbon, nitrogen and phosphorus concentrations were collected on alternate days at 07:00 h. Since the water column was well mixed, as confirmed by CTD profiles obtained during the experiment, integrated water samples $(0-13 \mathrm{~m})$ were taken. A core of the water column in the mesocosms was collected by lowering a $13 \mathrm{~m}$ long tube in the water column, and then retrieving the tube from its lower end so as to collect the entire core of the water column into a 301 jar, where it was thoroughly mixed before subsampling within $30 \mathrm{~min}$, for analyses. Sediments accumulating at the bottom of the bags were removed at intervals of about $4 \mathrm{~d}$ by pumping a volume of water through a hose connected to the terminal apex of the lower cone closing each of the mesocosms. Pumping was, however, not quantitative, since there was no means to verify that all of the sediments had been removed, and visual inspections by divers confirmed that a substantial amount of sediment remained after pumping, mostly deposited in folds slightly above the apex of the cone and attached to the walls of the enclosure. Hence, a carbon mass balance model was used to estimate the sedimentation rate of carbon (Olsen unpubl. results), and the $\mathrm{C}: \mathrm{N}$ and $\mathrm{C}: \mathrm{P}$ ratios of the sediment material sampled were used to convert the carbon estimates to estimates of nutrient deposition.

Subsamples for dissolved inorganic nutrient analysis were taken and the concentrations measured spectrophotometrically following standard methods (Grasshoff et al. 1999), using a $10 \mathrm{~cm}$ cuvette when necessary to increase the detection limit. Subsamples for particulate carbon, nitrogen and phosphorus (POC, PON and POP, respectively) determinations were screened through a $200 \mu \mathrm{m}$ net and collected into 101 plastic containers, where they were thoroughly mixed. A variable water volume was immediately filtered through precombusted $\left(450^{\circ} \mathrm{C}, 2 \mathrm{~h}\right)$ Whatman GF/F glass-fiber filters for POC, PON and POP analyses. Additional subsamples were taken in 4 of the 7 mesocosms (that with no nutrients added, the 'business as usual' control and those with 4- and 16-times the control) for the size fractionation of POC, PON and POP. One aliquot was immediately filtered through precombusted $\left(450^{\circ} \mathrm{C}, 2 \mathrm{~h}\right)$ Whatman GF/F glass-fiber filters, thereby providing 2 replicates for the total POC, PON and POP concentrations in the 4 selected mesocoms. Two more aliquots were collected, one prefiltered through a $20 \mu \mathrm{m}$ net and the other through a $2 \mu \mathrm{m}$ Nuclepore filter, and the filtrate recovered on Whatman GF/F filters. Two consecutive filtrations were performed to increase the recovery of microparticles (Taguchi \& Laws 1988). Whatman GF/F glass-fiber filters have been proven to effectively retain particles below $0.5 \mu \mathrm{m}$ (Sheldon 1972) and to have similar retention properties as $0.2 \mu \mathrm{m}$ membrane filters (Taguchi \& Laws 1988, Chavez et al. 1995). More- over, the filters have been found to adequately sample picoplankton in oligotrophic open waters ( $\mathrm{Li}$ et al. 1983). Accordingly, the size-fractionation protocol used allowed the separation of 3 size components of the plankton community: from $\sim 0.2-2,2-20$ and $20-200 \mu \mathrm{m}$. The vacuum pressure differential was kept below $100 \mathrm{~mm} \mathrm{Hg}$ and precautions were taken to prevent exposure of the filters to air during filtration. Separate filters were collected for POC:PON and POP determinations. The filters with particulate matter were immediately placed in plastic vials and kept frozen $\left(-20^{\circ} \mathrm{C}\right)$ until further processing.

POC and PON were analysed in a Carlo-Erba CHN analyser after thawing the filters in an atmosphere of $\mathrm{HCl}$ fumes to remove carbonate and then drying at $60^{\circ} \mathrm{C}$. POP was determined following oxidation, at $120^{\circ} \mathrm{C}$ for $1.5 \mathrm{~h}$, of the filter in acidic persulfate and subsequent analysis of the dissolved phosphate (Ridal \& Moore 1990, Grasshoff et al. 1999). Blanks were determined from filters that had undergone every step in the procedure, including the loading into filter holders, and had been washed with 0.21 distilled water.

\section{RESULTS}

Nutrient concentrations at the onset of the experiment were very low (dissolved inorganic nitrogen $<0.05 \mu \mathrm{M}$, phosphate $=0.01$, Fig. 1), among the lowest
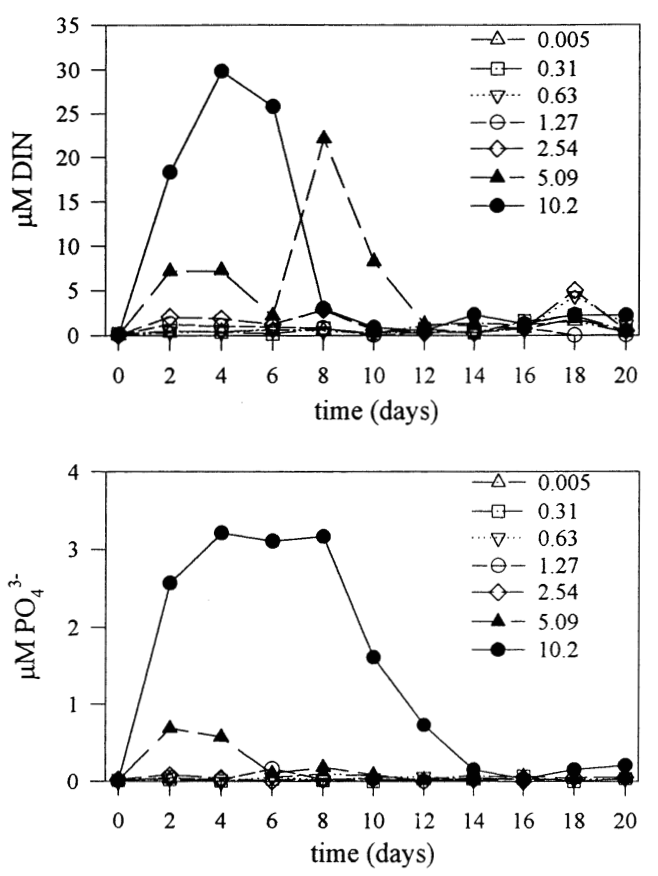

Fig. 1. Evolution of dissolved inorganic nutrient concentration in response to increased nutrient inputs to the mesocosms. DIN $=$ dissolved inorganic nitrogen $\left(\mathrm{NO}_{3}{ }^{-}+\mathrm{NO}_{2}{ }^{-}+\mathrm{HH}_{4}{ }^{+}\right)$. Symbols indicate the nutrient input, expressed as $\mu \mathrm{M} \mathrm{N} \mathrm{d}^{-1}$ 
values recorded during a 7 yr monitoring programme in the Bay of Blanes (Duarte unpubl. data). The nutrients added were rapidly assimilated by the community, so that nutrient accumulation was only observed after increasing nutrient inputs 4 - (for nitrogen) to 8fold (for phosphorus) above the 'business as usual' value (Fig. 1). After a delay of 4 to $8 d$, the communities present in the mesocosms were able to assimilate the inorganic nutrients accumulated, so that by the end of the experiment nutrient concentrations were low $(<0.1$ for dissolved inorganic nitrogen, $<0.2 \mu \mathrm{M}$ for phosphate, $<2 \mu \mathrm{M}$ for silicate) in all mesocosms (Fig. 1, Duarte et al. 2000a).

Before the addition of nutrients (18 June) the concentrations of carbon, nitrogen and phosphorus (hereafter POC, PON and POP) in the whole microplankton community (less than $200 \mu \mathrm{m}$ in size) were $16.8 \pm 1.28$, $2.2 \pm 0.12$ and $0.11 \pm 0.012 \mu \mathrm{M}$, respectively. The concentrations of POC, PON and POP reached values 10 times larger than the initial values (248 $\mu \mathrm{M}$ POC $20 \mu \mathrm{M}$ PON and $1 \mu \mathrm{M}$ POP) in the enclosure with 16fold nutrient input over the 'business as usual' control by the end of the experiment. This value was, respectively, 5.3, 4.5 and 7.3 times the POC, PON and POP present in the control at the end of the experiment.

POC increased in the mesocosms after an initial lag of 6 to $12 \mathrm{~d}$, depending on the enclosures (Fig. 2). The increased biomass was mostly contributed by organisms in the 2-20 $\mathrm{mm}$ size class, which incremented their POC concentration to 100 -fold that initially present (Fig. 2). In contrast, picoplankton increased mod- erately, to as much as 3.2-fold the initial value, while POC in the 20-200 $\mu \mathrm{m}$ range was mostly variable, decreasing in half of the enclosures and increasing to 3 - and 4 -fold in the remainder. As a result, there was a shift in the distribution of POC in the community, from an initial dominance of the picoplankton fraction to an increasing dominance of the nanoplankton $(2-20 \mu \mathrm{m})$ fraction. Conspicuous increases in POC were mostly noticeable after the nutrient inputs were increased 16 fold over the 'business as usual' loading.

Excess accumulation of $\mathrm{N}$ and $\mathrm{P}$ in relation to $\mathrm{C}$ with increasing nutrient inputs was found during the first week of the experiment following the addition of nutrients. As a result, C:N:P ratios decreased with nutrient inputs, from the initial 164:21:1 ratio to a value as low as 42:8:1 at the highest nutrient input (Fig. 2). Yet, $\mathrm{C}: \mathrm{N}: \mathrm{P}$ ratios approaching the Redfield value were only found after the nutrient additions were increased 4fold the 'business as usual' nutrient input. The storage capacity for phosphorus in this initial phase far exceeded that for nitrogen, with $\mathrm{N}: \mathrm{P}$ ratios decreasing from 19.3 to 8.2 along the gradient of nutrient additions. This trend was reversed at the end of the experiment, when $\mathrm{C}: \mathrm{N}: \mathrm{P}$ ratios increased to a value of 164:16:1 in the enclosure receiving the highest nutrient loading. There was, therefore, an overall trend of decreasing the $\mathrm{C}: \mathrm{N}: \mathrm{P}$ ratios along the gradient of nutrient additions (Fig. 3). Stoichiometric variations were mostly attributable to changes in the 2-20 $\mu \mathrm{m}$ size component, whereas the pico-sized fraction showed less variability. Enhanced C:P and N:P ratios were
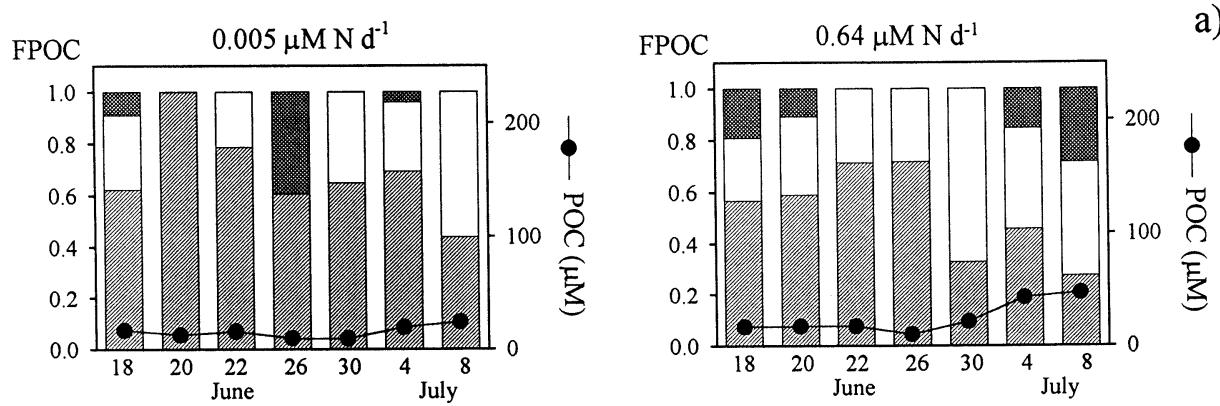

a)
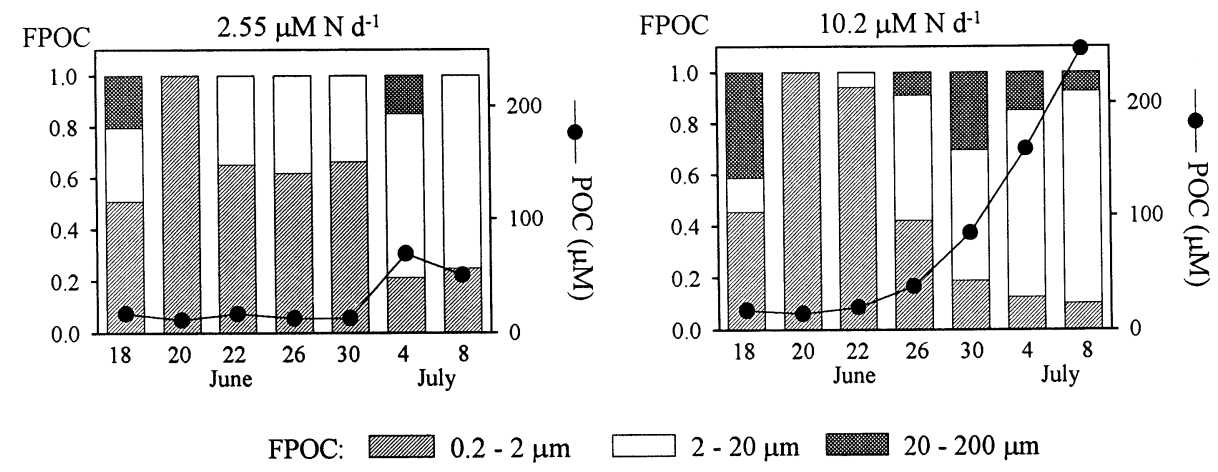

Fig. 2. Time course of partitioning among size classes, elemental ratios and concentrations of particulate nutrients in 4 enclosures with different nutrient additions (expressed in terms of nitrogen): (a) particulate organic carbon (POC), (b) particulate organic nitrogen (PON) and (c) particulate organic phosphorus (POP). FPOC, FPON and FPOP refer to the fraction of POC, PON and POP in each size component 

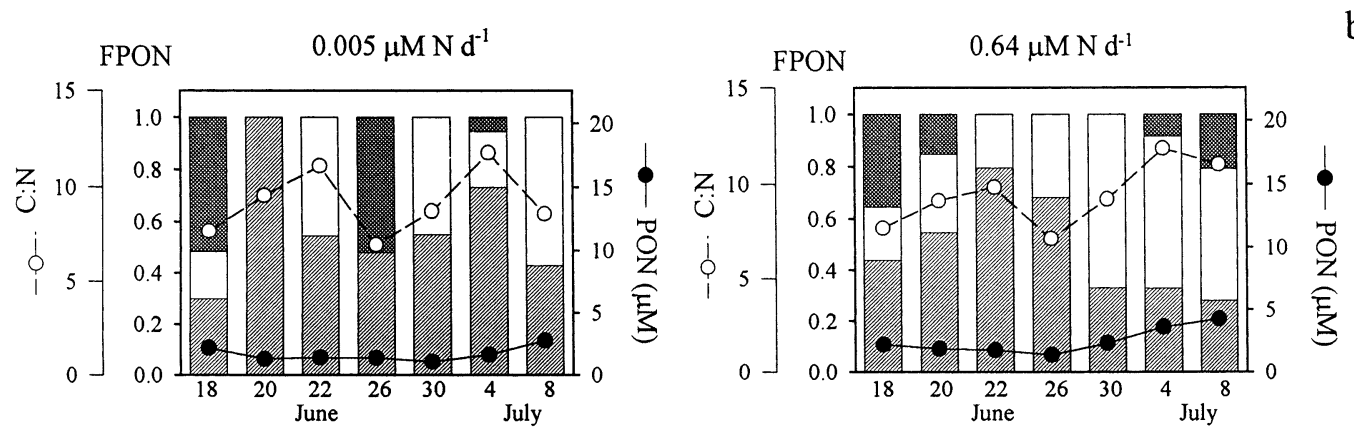

b)
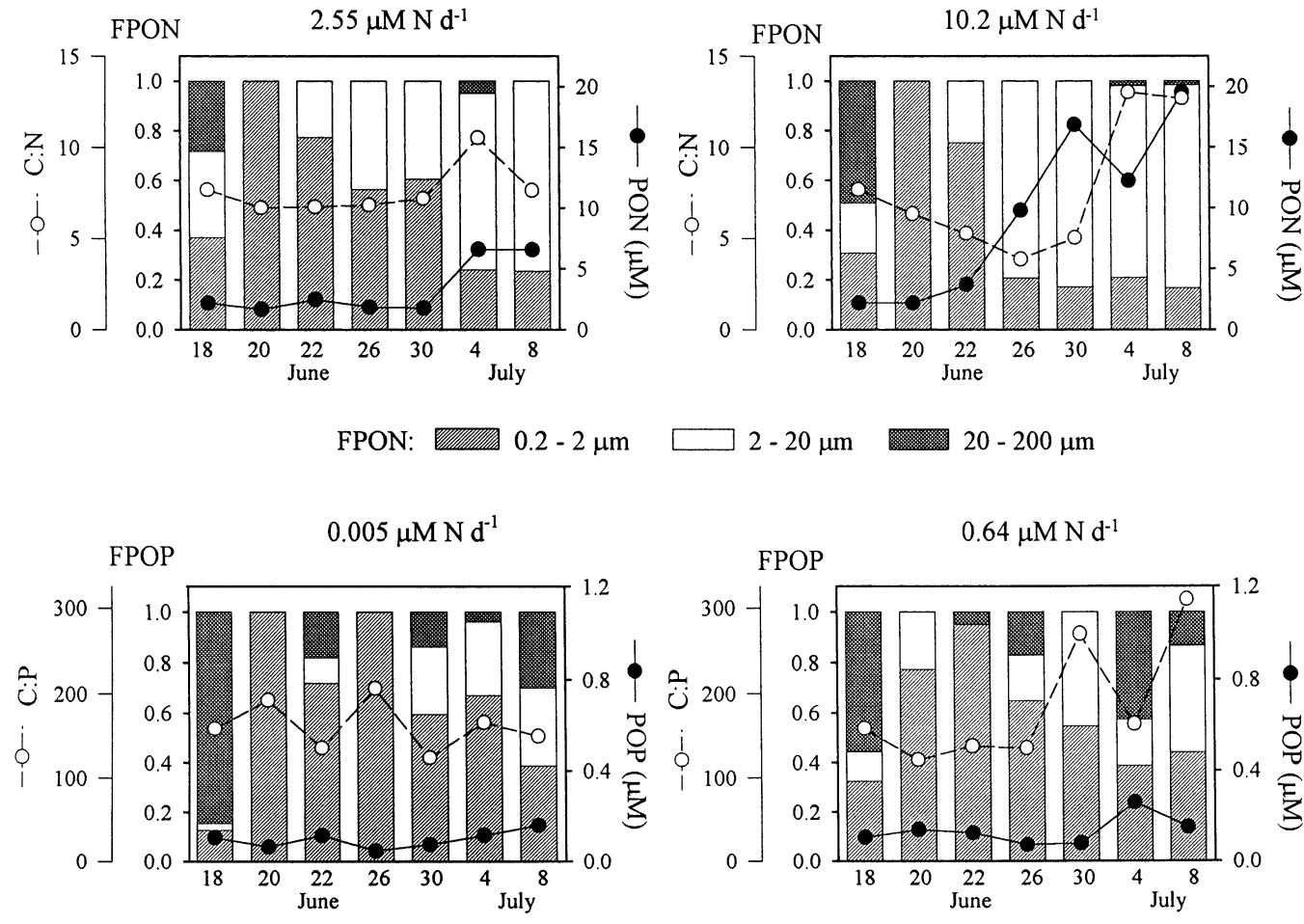

$2-20 \mu \mathrm{m} 20-200 \mu \mathrm{m}$
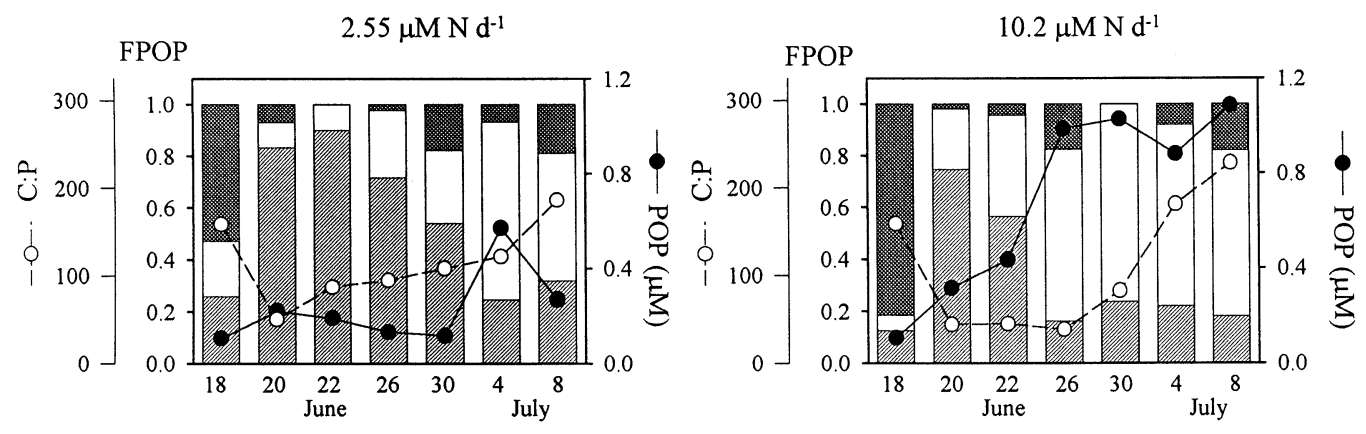

FPOP

บाIIIII) $0.2-2 \mu \mathrm{m}$

$2-20 \mu \mathrm{m}$

$20-200 \mu \mathrm{m}$

Fig. 2 (continued)

found in the $2-20 \mu \mathrm{m}$ fraction receiving the 'business as usual' nutrient load, compared to that of zero load, these ratios decreasing as the nutrient input increased. Very low C:N:P ratios, below that of picoplankton, were reached in the $2-20 \mu \mathrm{m}$ fraction after the first week of the experiment (average for June 26 and 30 in Fig. 3), with the ratios increasing towards the end of the experiment (average for July 4 and 8 in Fig. 3).

The final POC, PON and POP concentrations in the enclosures (average for July 4 and 8) were closely re- 
a) $0.2-2 \mu \mathrm{m}$
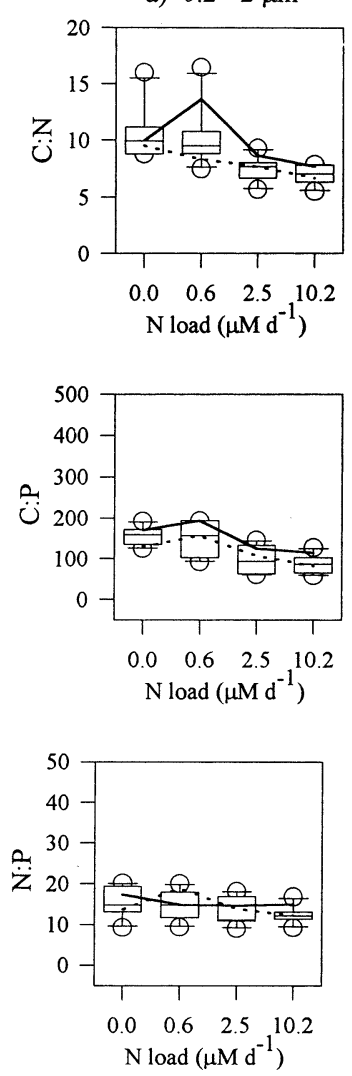

b) $2-20 \mu \mathrm{m}$
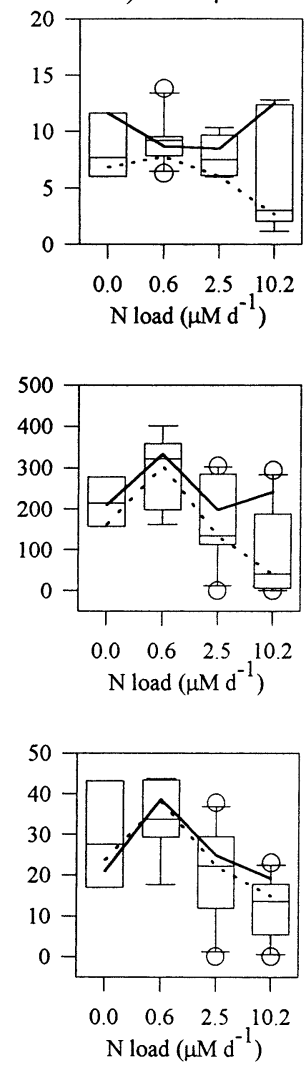

c) $0.2-200 \mu \mathrm{m}$
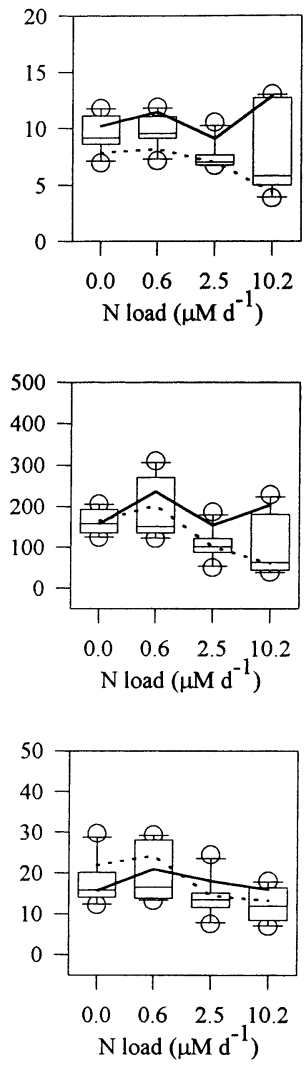

$\ldots \ldots$ average $26 / 06 \& 30 / 06$

average $4 / 07 \& 8 / 07$

Fig. 3. Box plots of the variation of elemental ratios (C:N, C:P and N:P) with nutrient load for different size components of the plankton community. Boxes encompass $50 \%$ of the data, the central line represents the median, the bars encompass the range of $90 \%$ of the values, and empty circles represent observations beyond the $90 \%$ percentile of the data, for all dates (given as $\mathrm{d} / \mathrm{mo}$ )

lated to the daily nutrient dosage, with a distinct pattern of increasing the contribution of the $2-20 \mu \mathrm{m}$ pool (Fig. 4a). Indeed, the partitioning of POC, PON and POP between size fractions was related to the nutrient input (Fig. 4b). There was a shift from an almost even distribution of these elements between size fractions in the 'business as usual' enclosure to a clearly uneven distribution, with dominance of the 2-20 $\mu \mathrm{m}$ size class, as the nutrient load increased. The pico-sized fraction dominated the elemental pools under poor nutrient conditions, as in the zero loading enclosure (Fig. 4b).

Significant linear relationships between average nutrient accumulation rates, computed from the slope of concentration against time plots, and daily nutrient dosage were found (Fig. 5), indicative of a constant rate of nutrient accumulation along the experimental nutrient gradient. Average nutrient accumulation rates ranged from $1.8 \pm 0.2,0.14 \pm 0.02$ and $0.005 \pm 0.001$ for
POC, PON and POP respectively, in the control receiving the 'business as usual' dose, to values between 5- and 10-fold higher (of $9.4 \pm 1.9,0.94 \pm 0.05$ and $0.05 \pm$ 0.01 for POC, PON and POP, respectively) after the nutrient load was increased 16fold. Increasing accumulation rates were mostly due to organisms in the $2-20 \mu \mathrm{m}$ size class, which contributed to $80-100 \%$ of the total accumulation (Fig. 6a). By contrast, picoplankton contributed little to the accumulation of nutrients, with values of 0.6 , 0.08 and $0.004 \mu \mathrm{M} \mathrm{d}^{-1}$ of POC, PON and $\mathrm{POP}$, respectively, at the highest nutrient loading enclosure, equivalent to only $10 \%$ of the accumulation rate in the $2-20 \mu \mathrm{m}$ size fraction.

Transient nutrient accumulation rates, computed between consecutive sampling days, 10 -fold above the average values were occasionally observed (Fig. 6b). Hence, the transient capacity of the plankton community to take up the added nutrients was far greater than their capacity for the long-term storage of the nutrients. The accumulation of nutrients in the established community at the end of the experiment represented a minor fraction of the nutrients added in each treatment, with an estimated efficiency for the storage of both $\mathrm{N}$ and $\mathrm{P}$ approaching $8 \%$ for the $2-20 \mu \mathrm{m}$ size organisms and being even lower, $<1 \%$, for the other components of the community (Fig. 7a). In comparison, highest transient efficiencies ranged from 14 to $300 \%$, with decreasing values, in most cases, along the gradient of nutrient additions (Fig. 7b). The same efficiency for the storage of both $\mathrm{N}$ and $\mathrm{P}$ indicated that the added nutrients were accumulated in stoichiometric balance with the input, with POC, PON and POP being accumulated at a ratio of $147 \mathrm{C}: 22 \mathrm{~N}: 1 \mathrm{P}$ in the pico-sized fraction and of $255 \mathrm{C}: 21 \mathrm{~N}: 1 \mathrm{P}$ in the $2-20 \mu \mathrm{m}$ size fraction.

The C:N and N:P ratios of the sediment material sampled averaged 18.0 and 82 , respectively, and the carbon mass balance indicated that sedimentation losses accounted for $18.3 \%$ of the primary production (range 11 to $22 \%$ ) across mesocosms. The corresponding $\mathrm{N}$ loss through sedimentation was equivalent to, on average, $16 \%$ of the inputs. Hence, the sum of particulate organic nutrients and the sedimented material did not account for all of the nutrients to the mesocosms. The rest of the nutrient inputs must have been either attached to the walls of the mesocosm (although calculations from subsamples of wall material for $\mathrm{N}$ and $\mathrm{P}$ determinations indicated this to represent $<5 \%$ of the 
a)
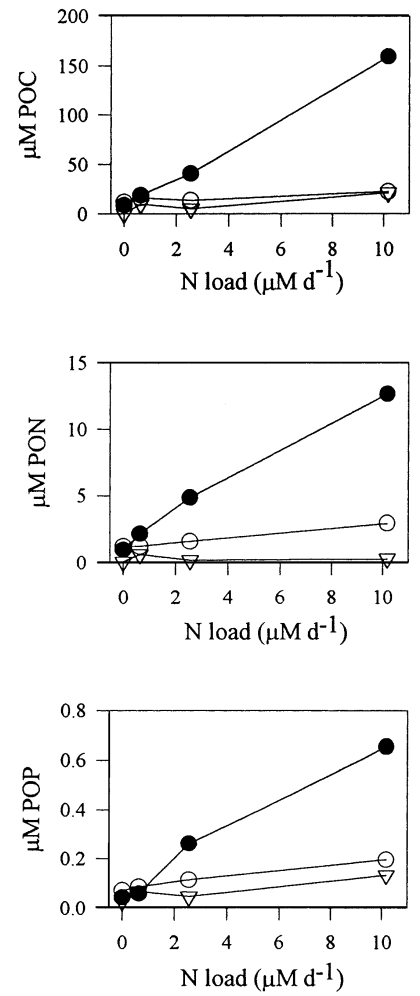

$-0.2-2 \mu \mathrm{m}$ b)
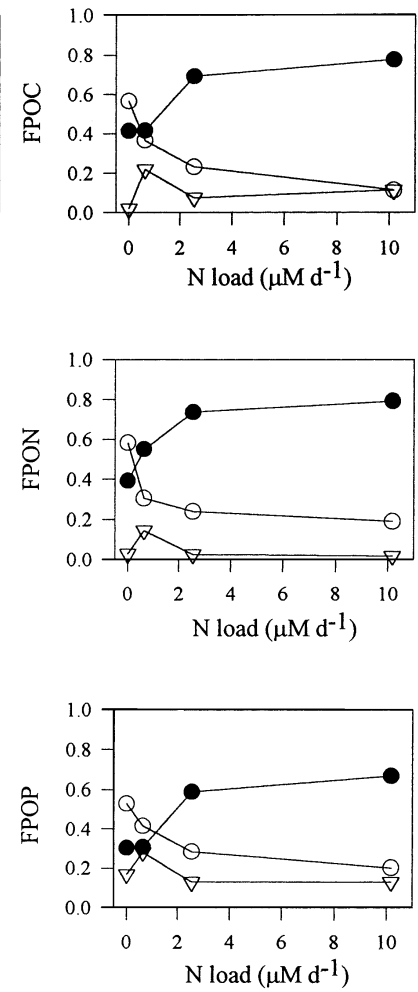

$2-20 \mu \mathrm{m} \rightarrow-20-200 \mu \mathrm{m}$
Fig. 4. (a) Final POC, PON and POP concentrations and (b) fraction of POC, PON and POP in each size component (FPOC, FPON and FPOP, respectively) along the gradient of nutrient additions (expressed in terms of nitrogen). Plotted data are averages for July 4 and 8

added nutrients), or retained by larger mesozooplankton (e.g. chaetognaths and other highly mobile zooplankton), which was not adequately represented in the determinations of $\mathrm{C}, \mathrm{N}$ and $\mathrm{P}$ from bulk water samples. Estimates of biomass from net tows (Duarte et al. $2000 \mathrm{~b}$ ) indicate that, at most, mesozooplankton could have accumulated about $10 \%$ of the nutrients added.

\section{DISCUSSION}

The conditions at the start of the experiment were those typical during summer in Mediterranean waters, characterised by low nutrient concentrations and low plankton biomass (Duarte et al. 1999). The community was initially dominated by heterotrophic bacteria, but also supported a biomass of protists and metazoan zooplankton comparable to that of autotrophs (Duarte et al. 2000b).

The POC, PON and POP concentrations in the enclosures after $2 \mathrm{wk}$ of nutrient additions increased
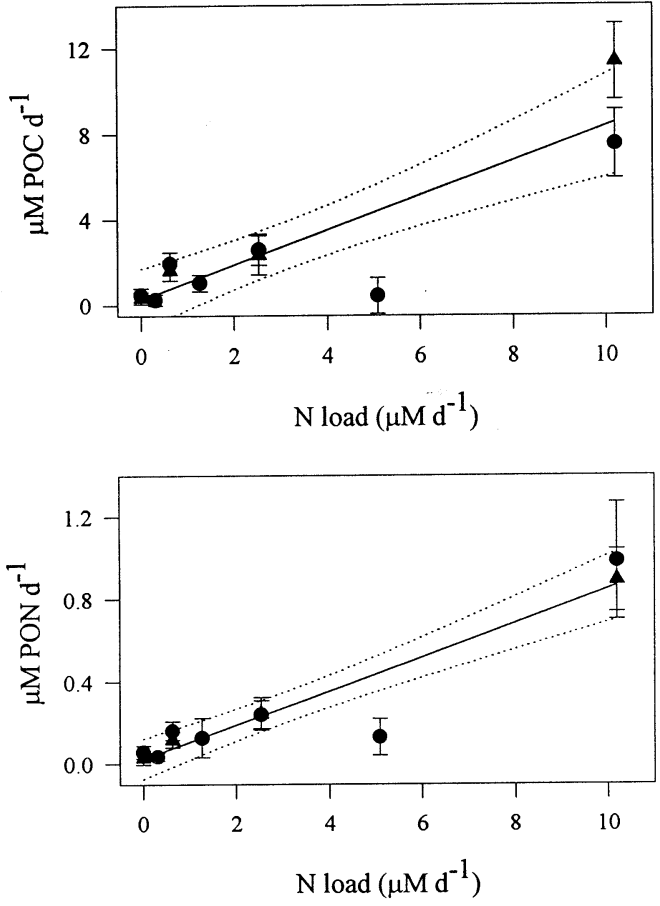

Fig. 5. POC and PON accumulation rates along the gradient of nutrient additions. Circles and triangles show independent data sets (see explanations in the 'Methods'). Dotted lines show the $95 \%$ confidence interval of the regression line, for both data sets

along the gradient of nutrient inputs (Fig. 4a), which is consistent with the general trend towards increasing the total carrying capacity of the system, in terms of nutrients, from oligotrophy towards eutrophy (Thingstad 1998). The initial biomass response to nutrient additions was, however, moderate, as a consequence of the moderate increase of the pico-sized fraction and the simultaneous decrease of the larger size component (Fig. 2). Lack of a biomass response to nutrient additions has been reported for Eastern Mediterranean waters (Pitta et al. 1998), Norwegian fjords (Jacobsen et al. 1995) and the Baltic Sea (Schiewer 1998). The early low biomass response of the plankton community to nutrient additions may be related to the initial community structure of the enclosed water, which was characterised by a high biomass of heterotrophs (Duarte et al. 2000b). A dominance of heterotrophic processes precludes the accumulation of biomass in plankton organisms, since it requires high respiratory losses (Satta et al. 1996), and suggests a dominant role of the dissolved organic pool in the nutrient fluxes. Indeed, dissolved organic $\mathrm{N}$ and $\mathrm{P}$ increased shortly ( $4 \mathrm{~d}$ ) after the initiation of the nutrient additions and then subsequently decreased (Duarte et al. unpubl. results), which is consistent with an inefficient channelling of nutrients to increase the 
a)
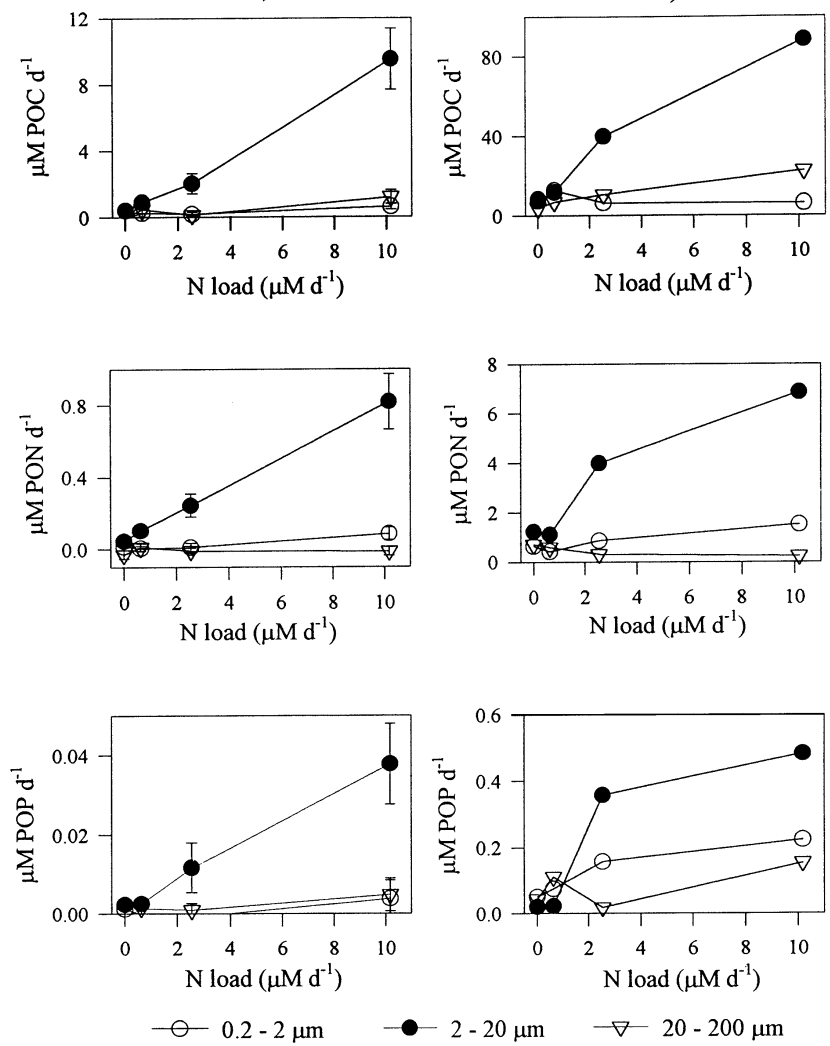

Fig. 6. Size-fractionated accumulation rates of $P O C, P O N$ and POP along the gradient of nutrient additions: (a) average accumulation rates, (b) highest transient accumulation rates (between consecutive sampling days) a)
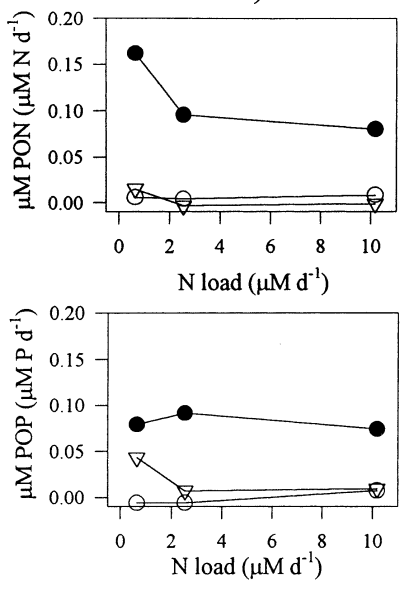

$-0.2-2 \mu \mathrm{m}$ b)
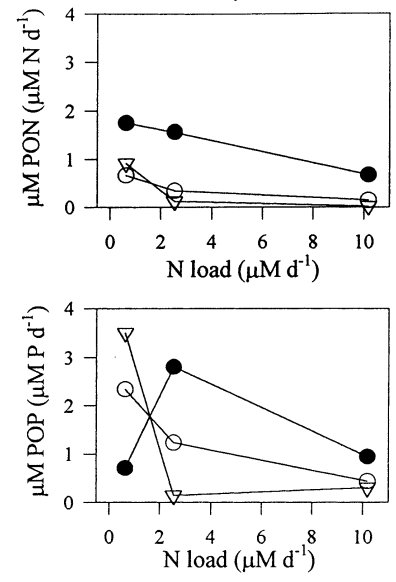

$\nabla 20-200 \mu \mathrm{m}$
Fig. 7. Size-fractionated PON and POP accumulation efficiencies along the gradient of nutrient additions: (a) average accumulation efficiencies, (b) highest transient accumulation efficiencies biomass during this initial phase. The initial pico-sized fractions showed a higher capacity for the storage of nutrients than carbon, which explained the decreasing POC:PON:POP ratios along the gradient of nutrient additions (Figs. $2 \& 3$ ). This capacity is attributable to the low carbon to nutrient ratios characteristic of these small organisms, in particular the C:P ratios, which confers picoplankton the ability to act as strong phosphorus sinks (Goldman et al. 1987, Chrzanowski \& Kyle 1996, Heldal et al. 1996).

The fast removal of the nutrients added to the enclosures (Fig. 1) and the high C:N:P ratios in the initial plankton community strongly suggest that the summer plankton community of the Bay of Blanes was nutrient limited. Evidence of nutrient limitation has been reported for Mediterranean waters in summer, when phosphorus was identified as the most probable limiting nutrient for phytoplankton communities (Krom et al. 1991, Zweifel et al. 1993, Vaulot et at. 1996, Thingstad et al. 1998, Zohary \& Robarts 1998). Yet, the concentration of dissolved inorganic $\mathrm{N}$ and $\mathrm{P}$ increased shortly (from Day 2) after nutrient additions were increased 4- (for nitrogen) and 8-fold (for phosphorus) the 'business as usual' value (Fig. 1). This indicates that, although the initial picoplankton assemblage was able to assimilate nutrients exceeding the already high summer loading of the Bay of Blanes, it was unable to take up nutrients above a certain threshold. This observation is consistent with the finding that the contribution of picoautotrophs to phytoplankton biomass and production declines as dissolved inorganic nitrogen concentrations increase above $1 \mu \mathrm{M}$ (Agawin et al. 2000a), and the finding that maximal growth rates for Synechococcus are reached at about $0.5 \mu \mathrm{M}$ of dissolved inorganic nitrogen (Agawin et al. 2000b). Picoplankton rarely build up large biomass stocks (Raimbault et al. 1988, Chisholm 1992, Agawin et al. 2000a), which has been related to strong predator pressure on picoplankton populations as the total nutrient content increases (Kuuppo-Leinikki et al. 1994, Agawin et al. 2000b). Hence, picoplankton-dominated communities, while acting as strong $\mathrm{N}$ and $\mathrm{P}$ sinks, seem to have a limited capacity to accumulate particulate nutrients, because of their low biomass development and the inefficient transference of these nutrients up the food web.

Conspicuous biomass increases found after $2 \mathrm{wk}$ of nutrient additions involved a change in the structure of the community, from a community dominated by picoplankton to a dominance of the $2-20 \mu \mathrm{m}$ size class. This result is consistent with existing models linking food-web structure to trophic conditions, which predict an increase in the overall size of the pelagic community following the increase in the total nutrient content of the system (Thingstad \& Sakshaugh 1990, Arm- 
strong 1994). The increase in size provides a refuge from predation (Verity \& Smetacek 1996), allowing an increase in biomass and production of the autotrophs. Indeed, the increased biomass in the enclosures receiving nutrient additions consisted largely of diatoms, namely Chaetoceros sp. and Licmophora sp. (Duarte et al. 2000b). In contrast, heterotrophic flagellates showed a much more modest increase, while ciliates and mesozooplankton showed no significant response to increased nutrient inputs (Duarte et al. 2000b). Hence, relief of the grazing pressure as the nutrient load increased should allow autotrophic organisms to increase their biomass and to assimilate part of the additional nutrients. This could explain the removal of dissolved inorganic nutrients, which had been accumulated during the first week of the experiment, soon after the biomass of the $2-20 \mu \mathrm{m}$ size fraction increased (Fig. 1). In fact, the $2-20 \mu \mathrm{m}$ size fraction contributed, by the end of the experiment, more than $90 \%$ of the $\mathrm{N}$ and $\mathrm{P}$ accumulated in the enclosure receiving the highest nutrient dosage (Fig. 4a).

Despite a significant increase in the nutrient pools contained in the particulate phase, the accumulation of nutrients in the Mediterranean community investigated was, with only $8 \%$ of the added nutrients stored in biomass by the end of the experiment, very low (Fig. 7a). In comparison, similar mesocosm experiments in the Baltic Sea and a Norwegian fjord yielded 40 to $60 \%$ efficiency in the trapping of nutrients (Kononen et al. 1993, Bleijswijk et al. 1994, Hein \& Riemann 1995). The low accumulation of nutrients in biomass was not the result of a low assimilation by osmotrophs, since there was little residual dissolved inorganic nutrients in any of the treatments by the end of the study (Fig. 1; Duarte et al. 2000a) and the established community showed symptoms of nutrient deficiency, as indicated by their high $\mathrm{C}: \mathrm{N}: \mathrm{P}$ ratios, by the end of the experiment (Figs. $2 \& 3$ ). Indeed, transient nutrient uptake efficiencies were very high (Fig. $7 \mathrm{~b}$ ), showing that $50 \%$ or even a greater fraction of the daily nutrient dosage could be rapidly transferred to the particulate pool following the nutrient additions. That the average accumulation efficiency, which reflects the long-term storage of nutrients in the food web, was low indicates that nutrient losses are of major importance in the functioning of the food web investigated. The average accumulation efficiencies were constant, at about $8 \%$ of the added nutrients, throughout the broad range of nutrient inputs (Fig. 7a), indicating that the turnover of nutrients remained unaltered despite major changes in food web structure along the gradient of nutrient inputs (Duarte et al. 2000b). This is consistent with similar findings concerning the turnover of carbon in phytoplankton (Duarte et al. 2000a) and with reports from similar studies showing increased plankton biomass in response to nutrient additions without changes in the relative community growth rate (Hein \& Riemann 1995, Schlüter 1998). These results also point to reduced losses, rather than to increased growth rates, as an important factor in the biomass response to nutrient additions. Loss rates have been shown to be a key factor in controlling phytoplankton populations in the NW Mediterranean coast (Mura et al. 1996), where phytoplankton mortality has been found to be very high, particularly in summer (Agustí et al. 1998). Loss factors may also be involved in the low efficiency for the trapping of nutrients in biomass found, as compared to some Atlantic waters. The factors responsible for the low accumulation of nutrients within organisms of less than $200 \mu \mathrm{m}$ in size may involve cell mortality (Agustí et al. 1998) and possibly the channelling of nutrients to larger components which may have escaped sampling (e.g. large mesozooplankton). Dolan et al. (1995) reported a very low efficiency of the plankton community to retain phosphorus, particularly in the presence of high grazing pressure, in the NW Mediterranean. A low capacity to retain phosphorus has also been demonstrated for plankton communities in the oligotrophic Atlantic Ocean (Cañellas et al. 2000), suggesting that this may be a characteristic of oligotrophic systems.

In summary, our results show the summer plankton community of the Bay of Blanes to be strongly nutrient (probably phosphorus) limited, resulting in high transient nutrient accumulation rates, but a very low capacity to maintain the nutrients incorporated within the food web. As a result, the warm oligotrophic Mediterranean plankton community developed a relatively low biomass in response to nutrient additions. Low plankton standing stocks seem to be a common characteristic throughout most of the Mediterranean coast, despite the increased nutrient loading in the last decade (Yilmaz et al. 1992, Mura et al. 1996). The tendency for a lower biomass response in the warm oligotrophic Mediterranean than in moderately eutrophic waters should have, if confirmed, profound implications for the management of the coastal zone and the delineation of critical nutrient loadings. Our results suggest that the summer Mediterranean plankton community can support high nutrient inputs without showing the accumulation of carbon and nutrients in particulate form demonstrated for some moderately eutrophic communities in the Atlantic. The loss processes by which a high nutrient turnover in the Mediterranean plankton community is maintained remain hypothetical and should be more thoroughly investigated to understand the apparent resilience in the response of Mediterranean plankton communities to increased nutrient inputs. 
Acknowledgements. This is a contribution to the project COMWEB, funded by the ELOISE program of the European Commission (contract number MAS3-CT96-0045), and a grant from the Spanish Commission for Science and Technology (CICYT MAR96-1715-CE). We thank J. Seppala, T. Tamminen, and the staff at Tallers FERM (Blanes, Spain) for advice in the design and construction of the mesocosms, A. Juán Sr and Jr for assistance with the operation of the mesocosms, and the Blanes Peix Company for permission to deploy the mesocosm platform in their concession. We also thank A. Lucea for nutrient analyses, I. Casals and P. Fernández from the Serveis Científico - Tècnics of the University of Barcelona for the C:N analysis, and 4 anonymous reviewers for useful comments on the manuscript.

\section{LITERATURE CITED}

Agawin NSR, Duarte CM, Agustí S (1998) Growth and abundance of Synechococcus sp. in a Mediterranean Bay: seasonality and relationship with temperature. Mar Ecol Prog Ser 170:45-53

Agawin NSR, Duarte CM, Agustí S (2000a) Nutrient and temperature control of the contribution of picoplankton to phytoplankton biomass and production. Limnol Oceanogr 45:591-600

Agawin NSR, Duarte CM, Agustí S (2000b) Response of Mediterranean Synechococcus growth and loss rates to experimental nutrient inputs. Mar Ecol Prog Ser 206:97-106

Agustí S, Satta MP, Mura MP, Benavent E (1998) Dissolved esterase activity as a tracer of phytoplankton lysis: evidence of high phytoplankton lysis rates in the northwestern Mediterranean. Limnol Oceanogr 43:1836-1849

Armstrong RA (1994) Grazing limitation and nutrient limitation in marine ecosystems: steady state solutions of an ecosystem model with multiple food chains. Limnol Oceanogr 39:597-608

Boynton WR, Kemp WM, Keefe CW (1982) A comparative analysis of nutrients and other factors influencing estuarine phytoplankton production. In: Kennedy VS (ed) Estuarine comparisons. Academic Press, New York, p 69-90

Boynton WR, Murray L, Hagy JD, Stokes C, Kemp WM (1996) A comparative analysis of eutrophication patterns in a temperate coastal lagoon. Estuaries 19:408-421

Cañellas M, Duarte CM, Agustí S (2000) Latitudinal variability in phosphate uptake in the Central Atlantic. Mar Ecol Prog Ser 194:283-294

Cebrián, J, Duarte CM, Pascual J (1996) Marine climate in the NW Mediterranean littoral. In: Duarte CM (ed) Seasonality in the Bay of Blanes: a paradigm of the northwest Mediterranean littoral. Publ Espec Inst Esp Oceanogr 22. Instituto Español de Occeanografía, Madrid, p 9-21

Chavez FP, Buck KR, Bidigare RR, Karl DM, Hebel D, Latasa M, Campbell L, Newton J (1995) On the chlorophyll a retentio properties of glass-fiber GF/F filters. Limnol Oceanogr 40:428-433

Chisholm SW (1992) Phytoplankton size. In: Falkowski PG, Woodhead AD (eds) Primary productivity and biogeochemical cycles in the sea. Plenum Press, New York, p 213-237

Chrzanowski TH, Kyle M (1996) Ratios of carbon, nitrogen and phosphorus in Pseudomonas fluorescens as a model for bacterial element ratios and nutrient regeneration. Aquat Microb Ecol 10:115-122

Cousins SH (1985) The trophic continuum in marine ecosystems: structure and equations for a predictive model. In: Ulanowicz RE, Platt T (eds) Ecosystem theory for biological oceanography. Can Bull Fish Aquat Sci 213:76-93
Dolan JR, Thingstad TF, Rassoulzadegan F (1995) Phosphate transfer between microbial size-fractions in Villefranche Bay (N. W. Mediterranean Sea), France in autumn 1992. Ophelia 41:71-85

Duarte CM, Agustí S, Kennedy H, Vaqué D (1999) The Mediterranean climate as a template for the Mediterranean marine ecosystem: the example of the NE Spanish littoral. Prog Oceanogr 44:245-270

Duarte CM, Agustí S, Agawin NSR (2000a) Response of a Mediterranean phytoplankton community to increased nutrient inputs: a mesocosm experiment. Mar Ecol Prog Ser 195:61-70

Duarte CM, Agustí S, Gasol JM, Vaqué D, VázquezDomínguez E (2000b) Effect of nutrient supply on the biomass structure of planktonic communities: an experimental test on a Mediterranean coastal community. Mar Ecol Prog Ser 206:87-95

Goldman JC, Caron DA, Dennett MR (1987) Regulation of gross growth efficiency and ammonium regeneration in bacteria by substrate C:N ratio. Limnol Oceanogr 32: 1239-1252

Grasshoff K, Ehrhardt M, Kremling K (1999) Methods of seawater analysis, 3rd edn. Verlag Chemie, Weinheim

Hagström Å, Azam F, Andersson A, Wikner J, Rassoulzadegan F (1988) Microbial loop in an oligotrophic pelagic marine ecosystem: possible roles of cyanobacteria and nanoflagellates in the organic fluxes. Mar Ecol Prog Ser 49:171-178

Hecky RE, Kilham P (1988) Nutrient limitation of phytoplankton in freshwater and marine environments: a review of recent evidence on the effects of enrichment. Limnol Oceanogr 33:796-822

Hein M, Riemann B (1995) Nutrient limitation of phytoplankton biomass or growth rate: an experimental approach using marine enclosures. J Exp Mar Biol Ecol 188:167-180

Heldal M, Norland S, Fagerbakke KM, Thingstad F, Bratbak G (1996) The elemental composition of bacteria: a signature of growth conditions? Mar Pollut Bull 33:3-9

Jacobsen A, Egge JK, Heimdal BR (1995) Effects of increased concentration of nitrate and phosphate during a springbloom experiment in mesocosms. J Exp Mar Biol Ecol 187:239-251

Kononen K, Lahdes EO, Grönlund L (1993) Physiological and community responses of summer plankton to nutrient manipulation in the Gulf of Finland (Baltic Sea) with special reference to phosphorus. Sarsia 78:243-253

Krom MD, Kress N, Brenner S, Gordon LI (1991) Phosphorus limitation of primary productivity in the eastern Mediterranean Sea. Limnol Oceanogr 36:424-432

Kuuppo-Leinikki P, Autio R, Hällfors S, Kuosa H, Kuparinen J, Pajuniemi R (1994) Trophic interactions and carbon flow between picoplankton and protozoa in pelagic enclosures manipulated with nutrients and a top predator. Mar Ecol Prog Ser 107:89-102

Li WKW, Subba RDV, Harrison WG, Smith JC, Cullen JJ, Irwin B, Platt T (1983) Autotrophic picoplankton in the tropical ocean. Science 219:292-295

Moloney CL, Field JG (1991) The size-based dynamics of plankton food webs. I. A simulation model of carbon and nitrogen flows. J Plankton Res 13:1003-1038

Mura MP, Agustí S, del Giorgio PA, Gasol JM, Vaqué, D, Duarte CM (1996) Loss-controlled phytoplankton production in nutrient-poor litoral waters of the NW Mediterranean: in situ experimental evidence. Mar Ecol Prog Ser 130:213-219

Oviatt C, Lane P, French F III, Donaghay P (1989) Phytoplankton species and abundance in reponse to eutrophi- 
cation in coastal marine mesocosms. J Plankton Res 11: $1223-1244$

Peters RH (1983) The ecological implications of body size. Cambridge University Press, Cambridge

Pitta P, Giannakourou, Divanach P, Kentouri M (1998) Planktonic food web in marine mesocosms in the Eastern Mediterranean: bottom-up or top-down regulation? Hydrobiologia 363:97-105

Platt T (1985) Structure of the marine ecosystem: its allometric basis. In: Ulanowicz RE, Platt T (eds) Ecosystem theory for biological oceanography. Can Bull Fish Aquat Sci 213 $55-64$

Raimbault P, Rodier M, Taupier-Letage I (1988) Size fraction of phytoplankton in the Ligurian Sea and the Algerian Basin (Mediterranean Sea): size distribution versus total concentration. Mar Microb Food Webs 3:1-7

Ridal JJ, Moore RM (1990) A re-examination of the measurement of dissolved organic phosphorus in seawater. Mar Chem 29:19-31

Satta MP, Agustí S, Mura MP, Vaqué D, Duarte CM (1996) Microplankton respiration and net community metabolism in a bay on the NW Mediterranean coast. Aquat Microb Ecol 10:165-172

Schiewer U (1998) 30 years' eutrophication in shallow brackish waters-lessons to be learned. Hydrobiologia 363: $73-79$

Schlüter L (1998) The influence of nutrient addition on growth rates of phytoplankton groups, and microzooplankton grazing rates in a mesocosm experiment. J Exp Mar Biol Ecol 228:53-71

Selmer JS, Ferrier-Pages C, Cellario C, Rassoulzadegan F (1993) New and regenerated production in relation to the microbial loop in the NW Mediterranean Sea. Mar Ecol Prog Ser 100:71-83

Sheldon RW (1972) Size separation of marine seston by membrane and glass-fiber filters. Limnol Oceanogr 17:494-498

Editorial responsibility: Otto Kinne (Editor), Oldendorf/Luhe, Germany
Taguchi S, Laws EA (1988) On the microparticles which pass through glass fiber filter type GF/F in coastal and open waters. J Plankton Res 10:999-1008

Tamminen T, Kuosa H (1998) Eutrophication in planktonic ecosystems: food web dynamics and elemental cycling Kluwer Academic Publishers, Dordrecht

Thingstad TF (1998) A theoretical approach to structuring mechanisms in the pelagic food web. Hydrobiologia 363: 59-72

Thingstad TF, Sakshaugh E (1990) Control of phytoplankton growth in nutrient recycling ecosystems. Theory and terminology. Mar Ecol Prog Ser 63:261-272

Thingstad TF, Zweifel UL, Rassoulzadegan F (1998) P limitation of heterotrophic bacteria and phytoplankton in the northwest Mediterranean. Limnol Oceanogr 43:88-94

van Bleijswijk JDL, Kempers RS, Wal P, van der, Westbroek P, Egge JK, Lukk T (1994) Standing stocks of PIC, POC, PON and Emiliania huxleyi coccospheres and liths in sea water enclosures with different phosphate loadings. Sarsia 79: 307-317

Vaulot D, LeBot N, Marie D, Fukai E (1996) Effect of phosphorus on the Synechococcus cell cycle in surface Mediterranean waters during summer. Appl Environ Microbiol 62:2527-2533

Verity PG, Smetacek V (1996) Organism life cycles, predation, and the structure of marine pelagic ecosystems. Mar Ecol Prog Ser 130:277-293

Yilmaz A, Bastürk Ö, Saydam C, Ediger D, Yilmaz K, Hatigplu E (1992) Eutrophication in Iskenderum Bay, northeastern Mediterranean. Sci Total Environ Suppl:705-717

Zohary T, Robarts RD (1998) Experimental study of microbial $\mathrm{P}$ limitation in the eastern Mediterranean. Limnol Oceanogr 43:387-395

Zweifel UL, Norrman B, Hagström ^̊ (1993) Consumption of dissolved organic carbon by marine bacteria and demand for inorganic nutrients. Mar Ecol Prog Ser 101:23-32

Submitted: December 6, 1999; Accepted: May 5, 2000

Proofs received from author(s): October 20, 2000 